\title{
Contribution of transrectal ultrasonography-guided biopsy in the diagnosis of prostate cancer: looking back and ahead
}

\author{
Contribuição da biópsia dirigida por ultrassonografia transretal no diagnóstico do câncer da próstata: olhando
} para os anos que passaram e para os anos que virão

\section{Sergio Ajzen ${ }^{1}$}

In the last 25 years we could witness the developments in the diagnosis, management and follow-up of prostate cancer, from open (large wound) surgeries to minimally invasive procedures and active surveillance. From the freehand transperineal biopsy technique $^{(\mathbf{1})}$ to the current transrectal ultrasonography-guided biopsy protocols, the malignancy prevalence has increased from about $20 \%^{(1)}$ to more than $50 \%$, as demonstrated by the prospective study published in the present issue of Radiologia Brasileira, developed by researchers of Hospital de Santarém, in Portugal ${ }^{(2)}$, where 155 patients were submitted to prostate biopsy without the knowledge about the prostate-specific antigen (PSA) values or results from previous sonographic studies. In the mentioned study, Lopes et al. collected 10 specimens as recommended by the European Association of Urology Guidelines on Prostate Cancer ${ }^{(3)}$, besides an additional specimen in cases where a nodule was considered suspicious. The reported malignancy prevalence was $53 \%$, with $74 \%$ positive predictive value. Innumerable, different biopsy protocols are regularly proposed, considering clinical/laboratory findings, and findings such as prostate volume and anatomy, among others.

In addition to the low prevalence of major complications ${ }^{(4-6)}$, there is no doubt that ultrasonography-guided prostate biopsy still plays a significant role in the cancer diagnosis, in spite of its controversial role in the screening for prostate cancer.

Despite the routine use of the PSA testing in the study of the prostate, over the last decade PSA levels and random prostate biopsy findings have allowed the diagnosis of some cancers, putting patients through unnecessary treatments for low-degree tumors which would have no consequence if left untreated. On the other hand,

1. Full Professor, Department of Imaging Diagnosis, Escola Paulista de Medicina da Universidade Federal de São Paulo (EPM-Unifesp), São Paulo, SP, Brazil. E-mail: sajzen@terra.com.br. such methods have failed to diagnose more advanced cases of cancer.

It should be considered that in spite of the slow growth of a great number of prostate cancers, in many cases they may present with an aggressive behavior and rapid development of metastasis, and hence the relevance of determining how and which patients should be treated.

Technological developments in imaging, such as elastography, magnetic resonance imaging-guided biopsy, magnetic resonance imaging-ultrasonography fusion, can revolutionize the way prostate cancer is detected.

Over the last decades, much has been told about cancer biological behavior and genetics. In spite of that knowledge be slowly applied in the daily practice, much has been done and I believe that in this next decade we shall witness the use of serum and urine biomarkers besides more effective strategies for diagnosis of prostate cancer, with screenings defining high-risk populations.

Technological developments in imaging in association with a greater genomic understanding will give a greater confidence about which patient should require active vigilance and will improve the detection of more aggressive cancers.

\section{REFERENCES}

1. Ajzen SA, Goldenberg SL, Allen GJ, et al. Palpable prostatic nodules: comparison of US and digital guidance for fine-needle aspiration biopsy. Radiology 1989;171: 521-3.

2. Lopes PM, Sepúlveda L, Ramos R, et al. 0 papel da ecografia transretal no diagnóstico do câncer da próstata: novas contribuições. Radiol Bras. 2015;48:7-11.

3. Heidenreich A, Bellmunt J, Bolla M, et al.; European Association of Urology. EAU guidelines on prostate cancer. Part 1: screening, diagnosis, and treatment of clinically localised disease. Eur Urol. 2011;59:61-71.

4. Solha RS, Ajzen S, De Nicola H, et al. Morbidade da biópsia da próstata transretal guiada por ultrassonografia. Radiol Bras. 2013;46:71-4.

5. Milito MA. Biópsia da próstata transretal guiada por ultrassonografia: suas complicações e morbidade são subestimadas? Radiol Bras. 2013;46(2):vii.

6. Tyng CJ, Maciel MJS, Moreira BL, et al. Preparo e manejo de complicações em biópsias de próstata. Radiol Bras. 2013;46:367-71. 